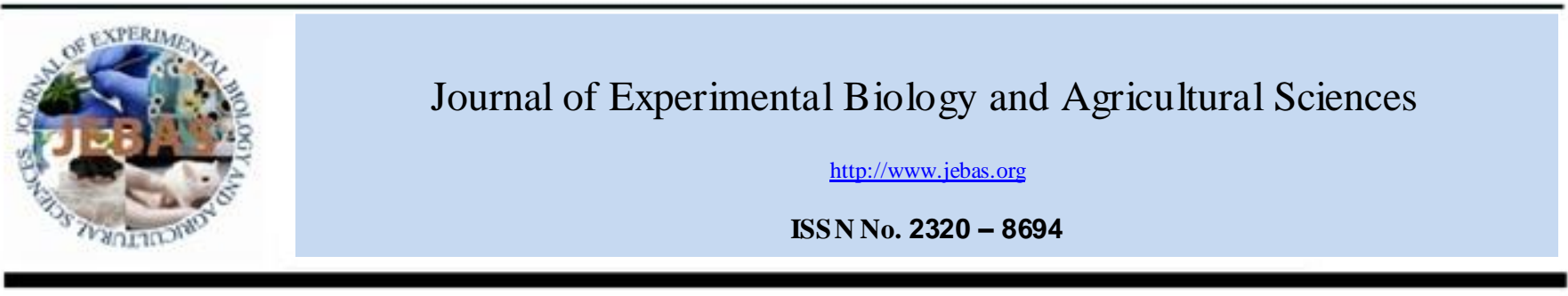

\title{
MAXIMIZATION OF GROUNDNUT (Arachis hypogaea L) YIELD BY NUTRIENT MANAGEMENT PRACTICES
}

\section{Madhu Bala* and Kedar Nath}

Regional Rice Research Station, Vyara-394650 Tal. Vyara Dist. Tapi (G), India

Received - March 06, 2015; Revision - April 01, 2015; Accepted - May 22, 2015

Available Online - June 19, 2015

DOI: http://dx.doi.org/10.18006/2015.3(3).241.245

\begin{abstract}
KEYWORDS
Arachis hypogaea

Yield

Treatments

Nutrient management

$\mathrm{BC}$ ratio

ABSTRAC T

Present study was carried out for finding the effect of nutrient management on the yield of the groundnut. The study was formulated in RCBD with 10 treatments and 4 replicates each. Results of the present investigation revealed a significant difference with respect of pod yield for all the studied treatments. Among the different treatments, highest pod yield was recorded by the treatment RDF $(100 \%$ as basal dose $)+$ FYM $(7.5 \mathrm{t} / \mathrm{ha}) 2169 \mathrm{~kg} / \mathrm{ha}$ with $\mathrm{BC}$ ratio 1:5.45 this improvement was followed by treatment $\operatorname{RDF}(100 \%$ as basal dose $)+\operatorname{RDF}(50 \%$ as top Dressing at $30 \mathrm{DAS})+\mathrm{FYM}(7.5 \mathrm{t} / \mathrm{ha})$ $2006 \mathrm{~kg} / \mathrm{ha}, 1: 4.66 \mathrm{BC}$ ratio and RDF (100\% as basal dose) $1966 \mathrm{~kg} / \mathrm{ha}$, BC ratio 1:4.59 and lowe st yield recorded by RDF (75\% as basal dose) + RDF (75\% as top Dressing at 30 DAS) $1721 \mathrm{~kg} / \mathrm{ha}$, BC ratio $1: 4.58$
\end{abstract}

* Corresponding author

E-mail: madhubala232@gmail.com (Madhu Bala)

Peer review under responsibility of Journal of Experimental Biology and Agricultural Sciences.

Production and Hosting by Horizon Publisher (www.myvision.webs.com/horizon.html).

All rights reserved.
All the article published by Journal of Experimental Biology and Agricultural Sciences is licensed under a Creative Commons Attribution-NonCommercial 4.0 International License Based on a work at www.jebas.org.

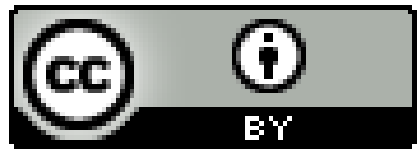




\section{Introduction}

Groun dnut or peanut (Arachis hypogaea L.) is also known as a 'King' of oilseed (Priya et al., 2013) belongs to family Fabaceae. This is also known by various names such as earthnuts, peanuts, goober peas, pindas, jack nuts, pinders, manila nuts, g-nuts and monkey nuts (Annadurai \& Palaniappan, 1994). Groundnut is an important oilseed crop of India, cultivated in various parts of the country. Among the various agronomic practices, nutrient management has an important role in maximizing the pod yield. Judicial use of fertilizers is necessary for increasing agricultural production and reduced environmental pollution because continuous use of chemical fertilizers has deleterious effects on soil which in turn cause decline in productivity. Furthermore it caused low nutrient recovery and increase in cost of production and environmental pollution (Sarkar et al., 1997). The optimization of the mineral nutrition has key role in optimization the production of groundnut because it has very high nutrient requirement. On contrary groundnut farmers use very less fertilizer resulting in severe mineral nutrient deficiencies due to inadequate and imbalance use of nutrients is one of the major factors responsible for low yield in groundnut (Veermani \& Subrahmaniyan, 2011). Thus it is high time to look into the mineral nutrition aspects of groundnut for achieving high yield and advocate the suitable package of practices for optimization of yield (Singh, 2004). Keeping in view the above facts, the present investigation was aimed to maximize the yield in groundn ut through nutrient management practices.

\section{Materials and Me thods}

Field experiment was conducted on Groundnut cv. GG-2 at Regional Rice Research Station, NAU, Vyara (Gujarat), India during three consecutive summer seasons from 2010 to 2012. The available nutrient in the soil at the initiation of trial is presented in table 1.Total ten treatments were tested in randomized complete block design with four replications (Table 2). Groundnut was sown @ $120 \mathrm{~kg}$ seed/ha in rows 30 $\mathrm{cm}$ apart and $10 \mathrm{~cm}$ plant to plant spacing. Initially recommended dose (25:50:00 NPK) of fertilizer were applied, as a source of nitrogen, urea was applied while as a source of phosphorus DAP was used during all the three years of study. All other treatments were imposed as per the schedule and methodologies given belo w.

\section{Results and Discussion}

Different fertilizer combination had a significant effect on pod yield of groundn ut. The data presented in Table 3 revealed that the pod yield $(\mathrm{kg} / \mathrm{ha})$ was highest $(2169 \mathrm{~kg})$ in the combination of RDF $(100 \%)+$ FYM $(7.5 \mathrm{t} / \mathrm{ha})$ which indicated that the yield components of summer groundnut like 100 pod weight, 100 kernel weight and shelling per cent were also increased as compared to the recommended dose of fertilizer (Table 5). This improvement was immediately followed by the treatment containing combination of RDF $(100 \%$ as basal dose $)+$ RDF $(50 \%$ as top Dressing at $30 \mathrm{DAS})+\mathrm{FYM}$ (7.5 t/ha) which showe $2006 \mathrm{~kg} / \mathrm{ha}$ yield.

Table 1 Available nutrient in the soil of the study area soil at the initiation of trial.

\begin{tabular}{ll} 
Soil organic carbon (\%) & 0.87 (Walkely and Black (wet oxidation $))$ \\
Av. $\mathrm{N}(\mathrm{kg} / \mathrm{ha})$ & $282\left(0.32 \%\right.$ Alkaline $\left.\mathrm{KMnO}_{4}\right)$ \\
\hline Av. $\mathrm{P}(\mathrm{kg} / \mathrm{ha})$ & $71.2\left(0.5 \mathrm{M} \mathrm{NaHCO}_{3}(\mathrm{pH} 8.5)\right)$ \\
\hline Av. $\mathrm{K}(\mathrm{kg} / \mathrm{ha})$ & $143\left(\right.$ Neutral $\left.\mathrm{N} \mathrm{NH}_{4} \mathrm{OAc}\right)$ \\
\hline Av. $\mathrm{S}(\mathrm{kg} / \mathrm{ha})$ & $12.64($ Tubidometric $)$ \\
\hline
\end{tabular}

Table 2 Nutrient treatments provided to groundnut during cultivation.

\begin{tabular}{|c|c|}
\hline S. No. & Treatments \\
\hline 1. & RDF (100\% fertilizers as basal dose) \\
\hline 2. & RDF (100\% fertilizers as basal dose) + FYM @ 7.5 t/ha \\
\hline 3. & $\mathrm{RDF}(75 \%$ as basal dose $)+\mathrm{RDF}(25 \%)$ as top Dressing at $30 \mathrm{DAS}$ \\
\hline 4. & $\mathrm{RDF}(75 \%$ as basal dose $)+\mathrm{RDF}(25 \%)$ as top Dressing at $30 \mathrm{DAS}+\mathrm{FYM} @ 7.5 \mathrm{t} / \mathrm{ha}$ \\
\hline 5. & $\mathrm{RDF}(150 \%$ as basal dose $)$ \\
\hline 6. & RDF $(150 \%$ as basal dose $)+$ FYM @ 7.5 t/ha \\
\hline 7. & $\operatorname{RDF}(100 \%$ as basal dose $)+\operatorname{RDF}(50 \%)$ as top Dressing at 30 DAS \\
\hline 8. & RDF $(100 \%$ as basal dose $)+\operatorname{RDF}(50 \%)$ as top Dressing at 30 DAS + FYM @ 7.5 t/ha \\
\hline 9. & $\operatorname{RDF}(75 \%$ as basal dose $)+\operatorname{RDF}(75 \%)$ as top Dressing at 30 DAS \\
\hline 10. & $\mathrm{RDF}(75 \%$ as basal dose $)+\mathrm{RDF}(75 \%)$ as top Dressing at $30 \mathrm{DAS}+\mathrm{FYM} @ 7.5 \mathrm{t} / \mathrm{ha}$ \\
\hline
\end{tabular}

Here RDF: Recommended do se of fertilizer, FYM: Farmyard manure, DAS: Days after sowing 
However, the treatment containing only RDF (100\%) was not significantly different than the treatment having combination of $\operatorname{RDF}(75 \%$ as basal dose) + RDF (25\% as top Dressing at 30 DAS + FYM (7.5 t/ha) but it is significantly lower than the combination of RDF (100\%) + FYM (7.5t/ha). Rests of the treatments were at par with each other and there were no significant differences among these treatments with respect to pod yield. The minimum pod yield $(1602 \mathrm{~kg} / \mathrm{ha})$ was noticed in the treatment containing RDF (75\% as basal dose) + RDF (75\% as top Dressing at $30 \mathrm{DAS})+$ FYM $(7.5 \mathrm{t} / \mathrm{ha})$.

Farmyard manure improved the physicochemical condition of the soil, provided favourable environment, stimulated the uptake of nutrients and increased the yield over the treatments where FYM was not added and the results are in confirmation to Mohapatra \& Dixit, 2010. The results were in confirmation to results obtained by Rao \& Shaktawat (2002).

The optimization of the mineral nutrition is the key to optimize the production of groundnut (Veeramani et al., 2012). The economic status of each treatment was determined by considering the cost of inputs used and gross returns (Table 4). In groundnut crop both pod yield and haulm yield have good market value. Highest gross monetary return (GMR Rs. $108450 \mathrm{ha}^{-1}$ ) was recorded by the treatment having RDF $(100 \%)+$ FYM (7.5t/ha). Followed by the combination of RDF (100\% as basal dose) + RDF (50\% as top Dressing at 30 DAS) + FYM (7.5 t/ha) and RDF (100\% as basal dose) with gross monetary return Rs. 100300 and Rs. 98300 respectively.

Here increase in net monetary return (NMR) is due to increase in GMR (Patil et al., 2003 \& Dwivedi \& Rawat, 2013). Benefit Cost ratio refers to monetary gain over each rupee of investment under the particular treatment.

The treatment containing combination of RDF $(100 \%$ as basal dose) + FYM (7.5 t/ha) was recorded maximum profitability (5.45) and this was followed by the combination of RDF $(150 \%$ as basal dose $) ; \operatorname{RDF}(75 \%$ as basal dose $)+\operatorname{RDF}(25 \%$ as top Dressing at $30 \mathrm{DAS})$ and $\mathrm{RDF}(100 \%$ as basal dose $)+$ RDF (50\% as top Dressing at 30 DAS) + FYM (7.5 t/ha) and these treatments were showing $4.91,4.72$ and 4.66 respectively. Thus it was revealed from the present investigation that integration of proper treatment combinations will definitely increase the pod yield $(\mathrm{kg} / \mathrm{ha})$ and profitability of groundnut crop with suitable nutrient management practices.

It can be concluded that adoption of a balanced nutrient management approach will safeguard the higher productivity and returns from money spent.

\section{Conflict of interest}

Authors would hereby like to declare that there is no conflict of interests that could possibly arise.

\section{References}

Annadurai K, Palaniappan SP (1994). Effect of K on yield, oil content and nutrient uptake of sunflower. Madras Agricultural Journal 81: 568-569.

Dwivedi BS, Rawat AK (2013) Nutrient management technology for niger (Guizotia abyssinica L. F.) crop in tribal areas. Plant Archives 13: 809-813.

Mohapatra AKB, Dixit L (2010) Integrated nutrient management in rainy season groundnut (Arachis hypogaea). Indian Journal of Agronomy 55: 123-127.

Patil BB, Ingavale MT, Mangave KK (2003) Optimization of safflower production under resource constraints. Madras Agricultural Journal 90: 731-732.

Rao SS, Shaktawat MS (2002) Effect of organic manure, phosphorus and gypsum on groundnut (Arachis hypogaea) production under rainfed condition. Indian Journal of Agronomy 47: 234-241.

Sarkar RK, Karmakar S, Chakraborty A (1997) Response of summer green gram (Phaseolus radiatus) to nitrogen, phosphorus application and bacterial inoculation.. Indian Journal of Agronomy 38: 578-581.

Priya RS, Chinnusamy C, Manicaksundaram P, Babu C (2013) A review on weed management in groundnut (Arachis hypogaea L.). International Journal of Agricultural Science and Research 3: 163-172.

Sin gh AL (2004) Mineral nutrient requirement, their disorders and remedies in groundnut. Groundnut Research in India 137 159.

Veeramani P, Subrahmaniyan K (2011) Nutrient management for sustainable groundnut productivity in India - a review. International Journal of Engineering Science and Technology 3:8138-8153.

Veeramani P, Subrahmaniyan K, Ganesaraja V (2012) Organic manure management on groundnut: A review. Wudpecker Journal of Agricultural Research1:238-243. 
Table 3 Pod yield of summer groundnut as influenced by different nutrient management practices.

\begin{tabular}{|c|c|c|c|c|}
\hline \multirow[t]{2}{*}{ Treatments } & \multicolumn{4}{|c|}{ Pod Yield } \\
\hline & 2010 & 2011 & 2012 & Pooled \\
\hline RDF ( $100 \%$ as basal dose $)$ & 2178 & 1897 & 1825 & 1966 \\
\hline RDF $(100 \%$ as basal dose $)+$ FYM $(7.5 \mathrm{t} / \mathrm{ha})$ & 2341 & 2070 & 2098 & 2169 \\
\hline $\mathrm{RDF}(75 \%$ as basal dose $)+\mathrm{RDF}(25 \%$ as top Dressing at $30 \mathrm{DAS})$ & 1547 & 1736 & 1932 & 1738 \\
\hline $\mathrm{RDF}(75 \%$ as basal dose $)+\operatorname{RDF}(25 \%$ as top Dressing at $30 \mathrm{DAS})+\mathrm{FYM}(7.5 \mathrm{t} / \mathrm{ha})$ & 2007 & 1802 & 1918 & 1909 \\
\hline RDF ( $150 \%$ as basal dose $)$ & 1931 & 1760 & 1774 & 1822 \\
\hline RDF $(150 \%$ as basal dose $)+$ FYM $(7.5 \mathrm{t} / \mathrm{ha})$ & 2007 & 1657 & 1741 & 1801 \\
\hline $\mathrm{RDF}(100 \%$ as basal dose $)+\mathrm{RDF}(50 \%$ as top Dressing at $30 \mathrm{DAS})$ & 2033 & 1588 & 1786 & 1802 \\
\hline $\mathrm{RDF}(100 \%$ as basal dose $)+\mathrm{RDF}(50 \%$ as top Dressing at $30 \mathrm{DAS})+\mathrm{FYM}(7.5 \mathrm{t} / \mathrm{ha})$ & 2180 & 2013 & 1825 & 2006 \\
\hline $\mathrm{RDF}(75 \%$ as basal dose $)+\mathrm{RDF}(75 \%$ as top Dressing at $30 \mathrm{DAS})$ & 1609 & 1601 & 1954 & 1721 \\
\hline $\mathrm{RDF}(75 \%$ as basal dose $)+\operatorname{RDF}(75 \%$ as top Dressing at $30 \mathrm{DAS})+\mathrm{FYM}(7.5 \mathrm{t} / \mathrm{ha})$ & 1531 & 1458 & 1809 & 1602 \\
\hline $\mathrm{SEm} \pm$ & 82 & 75 & 46 & 40 \\
\hline $\operatorname{LSD}(\mathrm{P}=0.05)$ & 238 & 218 & 133 & 114 \\
\hline $\mathrm{CV} \%$ & 8.45 & 8.54 & 4.92 & - \\
\hline
\end{tabular}

Table 4 Economics as influenced by different nutrient management practices in summer groundnut .

\begin{tabular}{|c|c|c|c|c|c|}
\hline Treatments & $\begin{array}{l}\text { Pod yield } \\
(\mathrm{Kg} / \mathrm{ha})\end{array}$ & $\begin{array}{c}\text { Cost of } \\
\text { cultivation } \\
\text { (Rs/ha) }\end{array}$ & $\begin{array}{l}\text { Gross monetary } \\
\text { retum (Rs/ha) }\end{array}$ & $\begin{array}{l}\text { Net return } \\
\text { (Rs/ha) }\end{array}$ & $\mathbf{B C R}$ \\
\hline RDF ( $100 \%$ as basal dose $)$ & 1966 & 20200 & 98300 & 78100 & 4.59 \\
\hline RDF $(100 \%$ as basal dose $)+$ FYM $(7.5 \mathrm{t} / \mathrm{ha})$ & 2169 & 19900 & 108450 & 88550 & 5.45 \\
\hline $\begin{array}{l}\text { RDF }(75 \% \text { as basal dose })+\mathrm{RDF}(25 \% \text { as top Dressing } \\
\text { at } 30 \text { DAS) }\end{array}$ & 1738 & 18400 & 86900 & 68500 & 4.72 \\
\hline $\begin{array}{l}\mathrm{RDF}(75 \% \text { as basal dose })+\mathrm{RDF}(25 \% \text { as top Dressing } \\
\text { at } 30 \mathrm{DAS})+\mathrm{FYM}(7.5 \mathrm{t} / \mathrm{ha})\end{array}$ & 1909 & 25540 & 95450 & 69910 & 3.74 \\
\hline $\mathrm{RDF}(150 \%$ as basal dose $)$ & 1822 & 18562 & 91100 & 72538 & 4.91 \\
\hline $\mathrm{RDF}(150 \%$ as basal dose $)+\mathrm{FYM}(7.5 \mathrm{t} / \mathrm{ha})$ & 1801 & 26662 & 90050 & 63388 & 3.38 \\
\hline $\begin{array}{l}\mathrm{RDF}(100 \% \text { as basal dose })+\mathrm{RDF}(50 \% \text { as top } \\
\text { Dressing at } 30 \text { DAS })\end{array}$ & 1802 & 20362 & 90100 & 69738 & 4.42 \\
\hline $\begin{array}{l}\mathrm{RDF}(100 \% \text { as basal dose })+\mathrm{RDF}(50 \% \text { as top } \\
\text { Dressing at } 30 \mathrm{DAS})+\mathrm{FYM}(7.5 \mathrm{t} / \mathrm{ha})\end{array}$ & 2006 & 21502 & 100300 & 78798 & 4.66 \\
\hline $\begin{array}{l}\mathrm{RDF}(75 \% \text { as basal dose })+\mathrm{RDF}(75 \% \text { as top Dressing } \\
\text { at } 30 \text { DAS) }\end{array}$ & 1721 & 18802 & 86050 & 67248 & 4.58 \\
\hline $\begin{array}{l}\mathrm{RDF}(75 \% \text { as basal dose })+\mathrm{RDF}(75 \% \text { as top Dressing } \\
\text { at } 30 \mathrm{DAS})+\mathrm{FYM}(7.5 \mathrm{t} / \mathrm{ha})\end{array}$ & 1602 & 26902 & 80100 & 53198 & 2.98 \\
\hline
\end{tabular}


Table 5 Yield components of summer groundnut as influenced by different nutrient management practices.

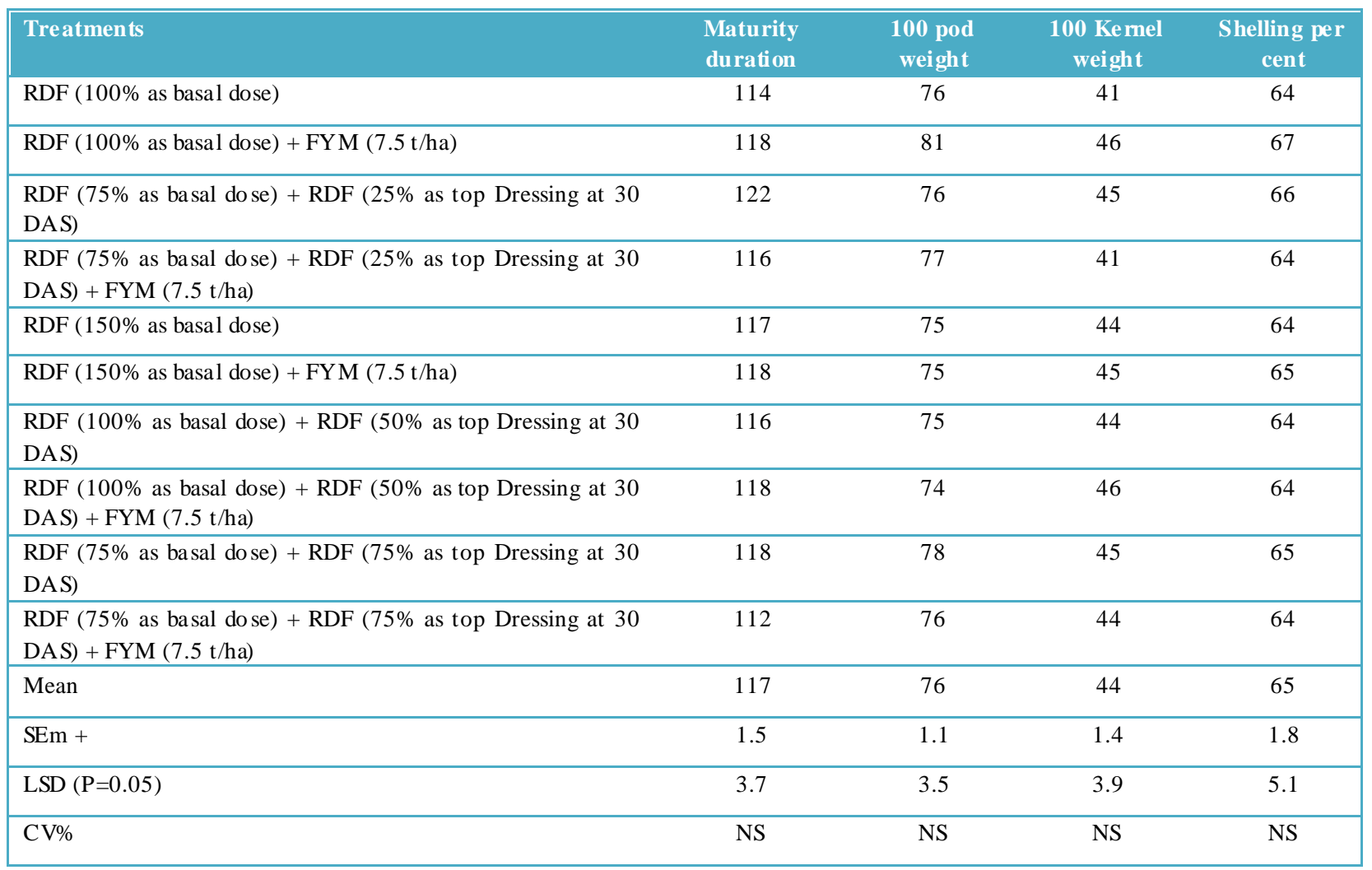

